\title{
The oldest Asian Sivaonyx (Lutrinae, Mustelidae): a contribution to the evolutionary history of bunodont otters
}

\author{
Camille Grohé, Louis de Bonis, Yaowalak Chaimanee, Cécile Blondel, \\ and Jean-Jacques Jaeger
}

\begin{abstract}
We describe here specimens of the otter Sivaonyx cf. gandakasensis from the late Middle Miocene hominoid-bearing basin of Chiang Muan, northern Thailand. Asian Sivaonyx species were previously recorded in the Late Miocene of the Siwalik Hills and Southern China. The new Thai remains could constitute the oldest occurrence of the genus in Asia (12.4-12.2 m.y.) and, more generally, in the Old World. S. gandakasensis, also occurring in the early Late Miocene and possibly Middle Miocene deposits of the Siwalik Hills, is the most primitive species of the genus. Based on the $\mathrm{m} 1 \mathrm{morphol}-$ ogy, we suggest a close relationship of this species with S. hessicus from the Late Miocene of Europe. In this study, we discuss the primitive morphological characters of Eurasian Sivaonyx compared to African ones, using notably the previously unknown M1 of S. cf. gandakasensis (e.g., developed M1 parastyle, high protoconid and narrow talonid basin on $\mathrm{m} 1$ ). Moreover, $S$. bathygnathus, the third and most derived Eurasian species known from the Late Miocene of the Siwaliks and Southern China, seems to be the most probable ancestor of Mio-Pleistocene African Sivaonyx. We therefore propose a dispersal of Sivaonyx from Asia to Africa during the Late Miocene, probably between ca. 10 and 7 m.y.
\end{abstract}

Camille Grohé. Institut des Sciences de l'Évolution de Montpellier (ISE-M, UMR-CNRS 5554) - Université Montpellier II, Place Eugène Bataillon, 34095 Montpellier Cedex 05, France

and Institut de Paléoprimatologie, Paléontologie Humaine: Évolution et Paléoenvironnements (IPHEP, UMR-CNRS 7262) - Bâtiment Sciences Naturelles, 40 av. Recteur Pineau - F86022 Poitiers Cedex, France camille.grohe@univ-montp2.fr

Louis de Bonis. Institut de Paléoprimatologie, Paléontologie Humaine: Évolution et Paléoenvironnements (IPHEP, UMR-CNRS 7262) - Bâtiment Sciences Naturelles, 40 av. Recteur Pineau - F86022 Poitiers Cedex, France louis.de.bonis@univ-poitiers.fr Yaowalak Chaimanee. Institut de Paléoprimatologie, Paléontologie Humaine: Évolution et Paléoenvironnements (IPHEP, UMR-CNRS 7262) - Bâtiment Sciences Naturelles, 40 av. Recteur Pineau F86022 Poitiers Cedex, France yao.chaimanee@univ-poitiers.fr

Cécile Blondel. Institut de Paléoprimatologie, Paléontologie Humaine: Évolution et Paléoenvironnements

PE Article Number: 16.3.29A

Copyright: Palaeontological Association December 2013

Submission: 24 May 2013. Acceptance: 4 November 2013

Grohé, Camille, Bonis, Louis, de, Chaimanee, Yaowalak, Blondel, Cécile, and Jaeger, Jean-Jacques. 2013. The oldest Asian Sivaonyx (Lutrinae, Mustelidae): a contribution to the evolutionary history of bunodont otters, Palaeontologia Electronica Vol. 16, Issue 3; 29A; 13p;

palaeo-electronica.org/content/2013/551-oldest-asian-bunodont-otters 
(IPHEP, UMR-CNRS 7262) - Bâtiment Sciences Naturelles, 40 av. Recteur Pineau - F86022 Poitiers Cedex, France cecile.blondel@univ-poitiers.fr

Jean-Jacques Jaeger. Institut de Paléoprimatologie, Paléontologie Humaine: Évolution et

Paléoenvironnements (IPHEP, UMR-CNRS 7262) - Bâtiment Sciences Naturelles, 40 av. Recteur Pineau F86022 Poitiers Cedex, France jean.jacques.jaeger@univ-poitiers.fr

Keywords: Carnivora; Mustelidae; Lutrinae; Southeast Asia; Thailand; Miocene

\section{INTRODUCTION}

The Lutrinae belongs to the Mustelidae, the most species-rich family of Carnivora. They are currently represented by 7 genera and 13 species occurring both in freshwater and coastal marine habitats throughout much of the continents (except Australia and Antarctica). Although otters exhibit a taxonomically diversified and worldwide fossil record since the Miocene (Willemsen, 1992; Pickford, 2007; Werdelin and Peigné, 2010), their phylogenetical relationships remain up to now controversial when based on morphological data (e.g., de Muizon, 1982; van Zyll de Jong 1987, 1991; Willemsen, 1992), and in conflict with the results suggested by molecular analyses (Koepfli and Wayne, 1998; Koepfli et al., 2008). For example, in these last analyses, the basal position of the giant otter Pteronura within the subfamily and the diphyly between the river otters Lutra and Lontra notably contribute to split the tribes used by morphologists. Morphological classifications of otters into different tribes are mainly based on dental characters, because of a fragmentary fossil record suffering from the lack of cranial and postcranial specimens. These classifications are therefore closely related to diet preferences. Bunodont otters (tribe Enhydrini after Willemsen, 1992 and tribes Enhydrini+Enhydriodontini after Pickford, 2007) constitute a diverse group of fossil and extant forms for which dentition seems to be adapted to hard item consumption (e.g., extant sea otter Enhydra). Some important generic controversy exists for this group and is covered later in this paper (see discussion). Fossil bunodont otters successfully occupied continental ecosystems of Eurasia, Africa and North America from the Miocene to the Pleistocene. One of the most charismatic and abundant genus of this group is Sivaonyx, known to include lion-sized gigantic predators. Sivaonyx is recorded in the Mio-Pliocene and possibly Pleistocene of Africa (Kenya, Ethiopia, Uganda, Chad, South Africa, Egypt), and in the Miocene of Asia (Siwalik Hills of Pakistan and India, Southern
China) and Europe (Germany, Turkey). In this study we describe new material of Sivaonyx recovered from the late Middle Miocene Ban Sa locality of the Chiang Muan Basin, northwestern Thailand. This material could represent the oldest occurrence of the genus in Asia and brings a new opportunity to discuss the primitive morphological characters of Asian Sivaonyx compared to African ones and to propose possible Miocene dispersal events between Southern Asia and Africa. This study aims to improve our knowledge on both the evolutionary history of otters and the faunal dispersals occurring between Africa and Asia during the Miocene.

\section{Geological Setting}

The Middle Miocene Ban Sa locality is located in the Chiang Muan Basin, one of the numerous intramontane Miocene fossiliferous basins of northern Thailand. The sediments of the Chiang Muan Basin are mainly composed of mudstones and sandstones intercalated with palaeosols and two main lignite beds (i.e., Lower and Upper Lignite Members), both providing fossil remains (see Benammi et al., 2004 and Coster et al., 2010 for lithological details and stratigraphic section of Ban Sa locality). The Chiang Muan coal mine is famous for exposing hominoid-bearing fossiliferous levels, yielding dental remains of the large-bodied genus Khoratpithecus, closely related to extant orangutans (Chaimanee et al. 2003, 2004). Hominoid associated mammal fauna includes the gomphotheriid proboscidean Tetralophodon cf. xialongtanensis, the suoids Parachleuastochoerus sinensis, Hippopotamodon cf. hyotherioides, Conohyus sindiensis, Pecarichoerus sminthos, the rhinocerotid Chilotherium (Subchilotherium) intermedium, the ruminants Dorcatherium, Eotragus, and Siamotragulus, and the castorid Steneofiber siamensis (Chaimanee et al., 2003; Pickford et al., 2004; Suganuma et al., 2006; Chavasseau et al., 2009; Suraprasit et al., 2011). Biochronological data suggested an age comprised between ca. 12 and 10 
m.y. for the Chiang Muan sequence based on the faunal comparison with Xiaolongtan locality, Yunnan Province of China (Pickford and Liu, 2001; Pickford et al., 2004). More recent paleomagnetical studies (Benammi et al., 2004; Coster et al., 2010) and correlations established with Mae Moh coal mine sediments in Thailand rather indicate an age of 12.4-12.2 m.y. for the Upper Lignite Member. In 2003, a Thai-French paleontological expedition found the first fossils of Carnivora from the Upper Lignite Member of the Ban Sa locality. This material constitutes the focus of our study.

\section{MATERIAL AND METHODS}

The material is composed of two isolated and well-preserved molars stored at the Department of Mineral Resources of Bangkok, Thailand (DMR). The proportions and morphology of the teeth as well as their stratigraphic location permit to attribute them to the same species. Abbreviations for other institutions and specimens cited in the text and tables are: AM, American Museum of Natural History, New York, NY; BAR, fossils from Baringo District, Community Museums of Kenya; CM, Chiang Muan fossils, Thailand; BMNH, Natural History Museum, London, England; BSPG, Bayerische Staatssammlung für Paläontologie und historische Geologie, Munich, Germany; GSI, Geological Survey of India, Calcutta; GSP-Y, Geological Survey of Pakistan, Quetta - Yale University, New Haven, CO; IVPP V, Institute of Vertebrate Paleontology and Paleoanthropology, Beijing, Vertebrate collection; KNM, Kenya National Museums, Nairobi: -KP Kanapoi; -LU Lukeino; NK, fossils from Nkondo, Uganda National Museum, Kampala; SAM PQ-L, Iziko South African Museum, Cape Town, collections from Langebaanweg; TM, fossils from TorosMenalla, Chad; YPM, Yale Peabody Museum, New Haven, CO; YV, Yunnan Vertebrate, China.

Measurements were taken with a digital caliper to the nearest $0.1 \mathrm{~mm}$. Abbreviations for description and measurements are: $\mathbf{L}$, maximum mesiodistal length; Llab and Lling, Iabial and lingual maximum mesiodistal length of $\mathrm{M} 1 ; \mathbf{m}$, lower molar; M, upper molar; MlabDling, maximum distance between mesiolabial corner and distolingual corner of M1; MlingDlab, maximum distance between mesiolingual corner and distolabial corner of $\mathrm{M} 1 ; \mathbf{W}$, maximum linguolabial width; Wdist, linguolabial width of M1 at the distal border.

\section{SYSTEMATIC PALAEONTOLOGY}

\author{
Order CARNIVORA Bowdich, 1821 \\ Suborder CANIFORMIA Kretzoi, 1943 \\ Infraorder ARCTOIDEA Flower, 1869 \\ Family MUSTELIDAE Fischer, 1817 \\ Subfamily LUTRINAE Bonaparte, 1838 \\ Genus SIVAONYX Pilgrim, 1931
}

Diagnosis (Pilgrim, 1932; pp.88). "Lutrinae of large size; having a P4 of an approximately quadrate shape with a moderately trenchant paraconemetacone blade; paracone somewhat stoutly built; metacone very slightly elongate; parastyle welldeveloped but low; with two internal cusps, protocone and hypocone, lower than the outer cusps, somewhat stoutened and expanded so that the basin-shaped area is contracted; with a strong internal cingulum; mandible with a ramus deeper than the length of $\mathrm{m} 1$; canine large; $\mathrm{p} 1$ singlerooted; p4 broad posteriorly, with a strong, outwardly situated posterior cusp and a broad cingulum, no anterior accessory cusp; m1 very broad; paraconid situated so as to be bisected by the median axis of the tooth; metaconid as high as paraconid; talonid broader than trigonid and approximately equal in length to it, basin-shaped, surrounded by a ring of cusps of which the entoconid is as well developed as the hypoconid; m2 small, oval."

Comments. Because a revision of all Sivaonyx species is beyond the scope of this paper and because some generic attributions are still debated (see discussion), we do not emend the diagnosis of Sivaonyx until more material could allow it. However, we revise some morphological features for the $\mathrm{m} 1$ and mention other ones for the M1 in light of the recent specimens assigned to the genus. The trigonid of Sivaonyx is low with approximately equal cusps, the protoconid is however higher than the paraconid and metaconid in the most primitive species (see description and comparisons). A ring of cusplets surrounding the talonid, and a similarly developed hypoconid-entoconid are not observed in all species (e.g., hypoconid higher than the entoconid in S. gandakasensis, entoconid higher than the hypoconid in S. hendeyi). As underlined by Peigné et al. (2008) and not mentioned in the original diagnosis, the labial cingulid is marked on $\mathrm{m} 1$, and the M1 shows a strong metaconule and a distinct notch between the paraconule and the protocone. Type species. Sivaonyx bathygnathus (Lydekker, 1884)

Other included species. S. africanus (Stromer, 1931), S. beyi Peigné et al., 2008, S. ekecaman (Werdelin, 2003), S. gandakasensis Pickford, 


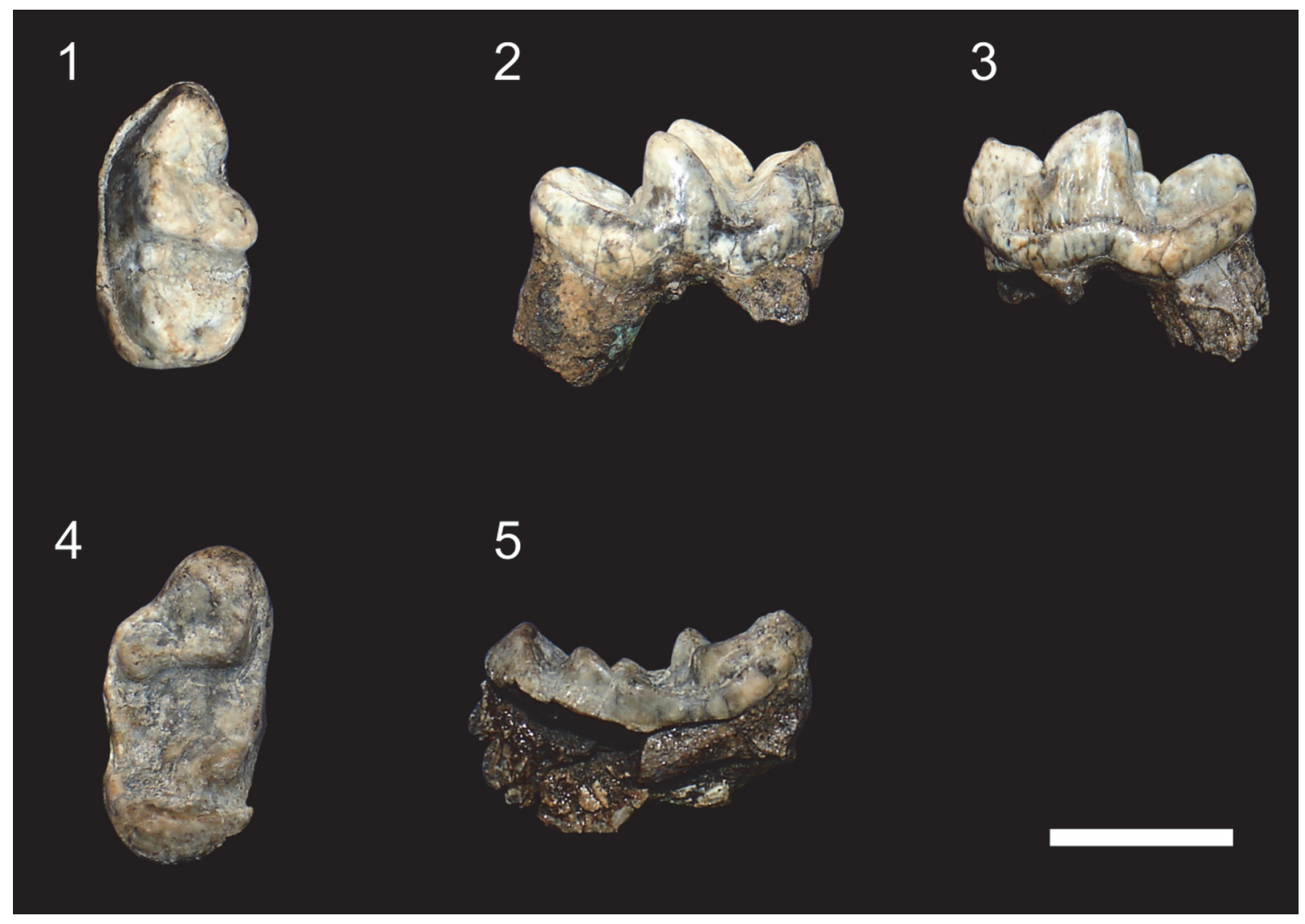

FIGURE 1. Sivaonyx cf. gandakasensis from the late Middle Miocene of Chiang Muan, Thailand: CM-03-A, left m1 in occlusal (1), lingual (2) and labial (3) views; CM-03-B, right M1 in occlusal (4) and mesial (5) views. Scale $=1 \mathrm{~cm}$.

2007, S. hendeyi (Morales et al., 2005), S. hessicus (Lydekker, 1890), S. kamuhangirei Morales and Pickford, 2005, S. soriae Morales and Pickford, 2005

Distribution. Late Miocene-Early Pleistocene of Africa (Egypt, Chad, Ethiopia, Kenya, Uganda, South Africa), Middle-Late Miocene of Asia (India, Pakistan, Thailand, China), Late Miocene of Europe (Germany, Turkey).

Sivaonyx cf. gandakasensis Pickford, 2007 Figure 1; Tables 1 and 2

Referred specimens. CM-03-A, left m1; CM-03-B, right M1 from Chiang Muan Basin, Thailand

Holotype locality. Locality Y182, Gandakas, Potwar Plateau of northern Pakistan - early Late Miocene (9.2 m.y. after Barry et al., 2002, same age as locality Y317 after Barry et al., 1982)

Distribution. Upper Lignite Member of the Chiang Muan Basin, northern Thailand - late Middle Miocene (12.4-12.2 m.y. after Benammi et al., 2004 and Coster et al., 2010)
Description. The left $\mathrm{m} 1$ shows a low trigonid as wide as the talonid and longer than it. The protoconid is higher than the paraconid and metaconid. The metaconid is slightly higher and is more lingual than the paraconid. The protoconid and the paraconid are separated by a well-marked carnassial notch. The paraconid has a nearly vertical mesial face and its distolingual crest does not extend more than the distolabial one and does not reach the lingual cingulid. Distal to this crest, a deep Vshaped valley separates the paraconid from the metaconid, contributing to a lingually opened trigonid. The metaconid is displaced distally with respect to the protoconid and is curved backwardly in lingual view. A small cuspule is present at the distal base of the protoconid. The talonid exhibits a tall hypoconid crest but lower than the paraconid, a weaker and curved entoconid crest, and a narrow and shallow talonid basin. The lingual border of the talonid appears oblique: it is lower and thicker near the metaconid relative to the distal end of the tooth. This height difference creates an acute angle between the distal face of the metaconid and the 
TABLE 1. Lower dental measurements of Sivaonyx species (in $\mathrm{mm}$ ). Measurements are from first hand and from ${ }^{1} \mathrm{Pil}-$ grim 1932; ${ }^{2}$ Colbert 1935; ${ }^{3}$ Qi 1983; 4Zong 1997; 5Werdelin 2003; 6 Morales et al. 2005; ${ }^{7}$ Morales and Pickford 2005; 8Pickford 2007; ${ }^{9}$ Peigné et al. 2008.

\begin{tabular}{|c|c|c|}
\hline & $\mathbf{L}$ & $\mathbf{W}$ \\
\hline \multicolumn{3}{|l|}{ Sivaonyx cf. gandakasensis } \\
\hline CM-03-A & 13.7 & 7.6 \\
\hline YPM 20206 & 15.4 & 8.5 \\
\hline \multicolumn{3}{|l|}{ S. gandakasensis } \\
\hline GSP-Y 4225 (holotype) 8 & 15 & 7.9 \\
\hline GSP-Y $11703^{8}$ & 13.9 & 7.9 \\
\hline GSI D $249^{8}$ & 14.4 & 8.6 \\
\hline BMNH M 13175 & 15.4 & 9.1 \\
\hline \multicolumn{3}{|l|}{ ?S. gandakasensis } \\
\hline BMNH G 4 & 12.8 & 7.6 \\
\hline \multicolumn{3}{|l|}{ S. bathygnathus } \\
\hline GSI D 33 (holotype) 8 & 17.1 & 9.7 \\
\hline GSI D 1561 & 16 & 9.4 \\
\hline GSI D $250^{8}$ & 16.4 & 9.1 \\
\hline AM $19509^{2}$ & 16.5 & 9.5 \\
\hline IVPP V $6886.12^{3}$ & 15.9 & 9 \\
\hline \multicolumn{3}{|l|}{ S. cf. bathygnathus } \\
\hline YV $2517^{4}$ & 14 & 8 \\
\hline \multicolumn{3}{|l|}{ S. hessicus } \\
\hline BMNH 27486 (holotype) & 15.9 & 8.6 \\
\hline \multicolumn{3}{|l|}{ S. beyi } \\
\hline TM 171-01-033 (holotype) ${ }^{9}$ & 20,3 & \\
\hline TM 172-05-0019 & 22,8 & 13,4 \\
\hline TM 355-02-0029 & 20 & 11,6 \\
\hline TM 247-01-0059 & 21,5 & 12,7 \\
\hline \multicolumn{3}{|l|}{ S. ekecaman } \\
\hline KNM-KP 10034 (holotype) ${ }^{5}$ & 21,2 & 13,5 \\
\hline BAR $720^{\prime} 03^{7}$ & & 12,8 \\
\hline BAR $567^{\prime} 05^{7}$ & 20,1 & 13 \\
\hline \multicolumn{3}{|l|}{ S. soriae } \\
\hline KNM-LU 337 \& 338 (holotype) ${ }^{6}$ & 17,6 & 10,5 \\
\hline BAR $1984^{\prime} 05^{7}$ & 17,5 & 10,6 \\
\hline \multicolumn{3}{|l|}{ S. hendeyi } \\
\hline SAM PQ-L 5000 (holotype) $^{9}$ & 21,3 & 13,1 \\
\hline \multicolumn{3}{|l|}{ S. kamuhangirei } \\
\hline Unnumbered (holotype) ${ }^{9}$ & 26 & 15,9 \\
\hline NK $1988 ' 897$ & & 14,4 \\
\hline \multicolumn{3}{|l|}{ S. africanus } \\
\hline BSPG 1930 XI 1 (holotype) ${ }^{9}$ & 22,2 & \\
\hline
\end{tabular}


TABLE 2. Upper dental measurements of Sivaonyx species (in mm). Measurements are from first hand and from ${ }^{1} \mathrm{Q} i$ 1983; 2Peigné et al. 2008.

\begin{tabular}{|c|c|c|c|c|c|}
\hline & Llab & Lling & Wdist & MlingDlab & MlabDling \\
\hline \multicolumn{6}{|l|}{ Sivaonyx cf. gandakasensis } \\
\hline CM-03-B & 7.6 & 7.1 & 14 & 10.7 & 14.2 \\
\hline \multicolumn{6}{|l|}{ S. bathygnathus } \\
\hline IVPP V 6886.31 & 9.3 & & 14 & & \\
\hline IVPP V $6886.5^{1}$ & 9.5 & & 14.6 & & \\
\hline \multicolumn{6}{|l|}{ S. beyi } \\
\hline TM 90-00-0662 & 11.7 & 11.7 & 17.3 & 16.5 & 20 \\
\hline \multicolumn{6}{|l|}{ S. soriae } \\
\hline BAR $1082^{\prime} 01^{2}$ & 11 & 12.2 & & 15.6 & 18.2 \\
\hline \multicolumn{6}{|l|}{ S. ekecaman } \\
\hline KNM-KP 10034 (holotype)² & 12.1 & 15.8 & 19 & & \\
\hline \multicolumn{6}{|l|}{ S. africanus } \\
\hline BSPG 1930 XI 1 (holotype)2 & 13 & 14.1 & 18.8 & 17.1 & \\
\hline
\end{tabular}

lingual talonid rim. The cingulid is thick on the labial side of the carnassial. It extends until the lingual base of the paraconid where it appears thinner. A shearing facet is visible on the upper part of the labial faces of the paraconid and protoconid.

The right $\mathrm{M} 1$ is broken at its most mesiolingual part so that the cingulum is interrupted at the paraconule-protocone level. The tooth is transversely widened. The mesial and distal borders are roughly parallel. The metacone is higher and mesiodistally shorter than the paracone. The paracone is more crestiform than the metacone. Both cusps are separated by a shallow notch. The labial shelf of the paracone is much wider than the metacone labial shelf. The parastyle is very long and extends from the paracone to join a wide cingulum surrounding the mesiolabial corner of the tooth. The paraconule and the protocone are crestiform, separated by a small notch, and constitute a blade along the mesial border of the tooth that bends distally at the protocone level. The protocone is as high as the paracone. The paraconule is located at a similar level as the metaconule but the latter is more prominent. Distally, the metaconule is not connected to the metacone. The labial crest descending from the metaconule joins the distal cingulum at the distolingual base of the metacone. A crescent-shaped cingulum is present at the distolingual corner of the tooth. It reaches approximately the height of the metacone. The thickest part of this cingulum is displaced mesially relative to the metacone. Both $\mathrm{m} 1$ and $\mathrm{M} 1$ show finely wrinkled enamel.

\section{COMPARISONS}

The wide talonid, the presence of a cuspule at the distal base of the protoconid, the high metaconid of $\mathrm{m} 1$, and its abrupt connection with the lingual talonid rim recalls the carnassial morphology of otters. Within Miocene otters, the morphology of the Chiang Muan material is closer to that of Sivaonyx than to that of any other genera (e.g., low trigonid cusps, high hypoconid, moderately deep talonid basin and rounded talonid rim on $\mathrm{m} 1$, presence of a metaconule on M1). Until now, nine species of Sivaonyx have been recorded from the Miocene of Eurasia and from the Mio-Pliocene of Africa. Several specimens of Sivaonyx sp. are also reported in the Plio-Pleistocene of Chad, Ethiopia and Kenya but are undescribed yet (Werdelin and Peigné, 2010). Here we compare the material from Chiang Muan to that of Eurasian and then African species of Sivaonyx. Dental measurements of $\mathrm{m} 1$ and M1 of Sivaonyx species are presented in Tables 1 and 2. Their stratigraphic and geographic distributions are illustrated in Figure 2.

The type species S. bathygnathus has long been the only Sivaonyx species recorded in Asia. Originally described from the Late Miocene of the Siwalik Hills of Pakistan (Hasnot, Potwar Plateau; Lydekker, 1884; Pilgrim, 1932), the species is also reported in the Late Miocene of Haritalyangar, India (Prasad, 1968), of Lufeng and possibly Yuanmou, Yunnan Province of China (Qi, 1979, 1983; Zong, 1997; Qi et al., 2006). The holotype of Sivaonyx bathygnathus (GSI D 33) is a mandible fragment with a poorly preserved $\mathrm{m} 1$, but the additional 


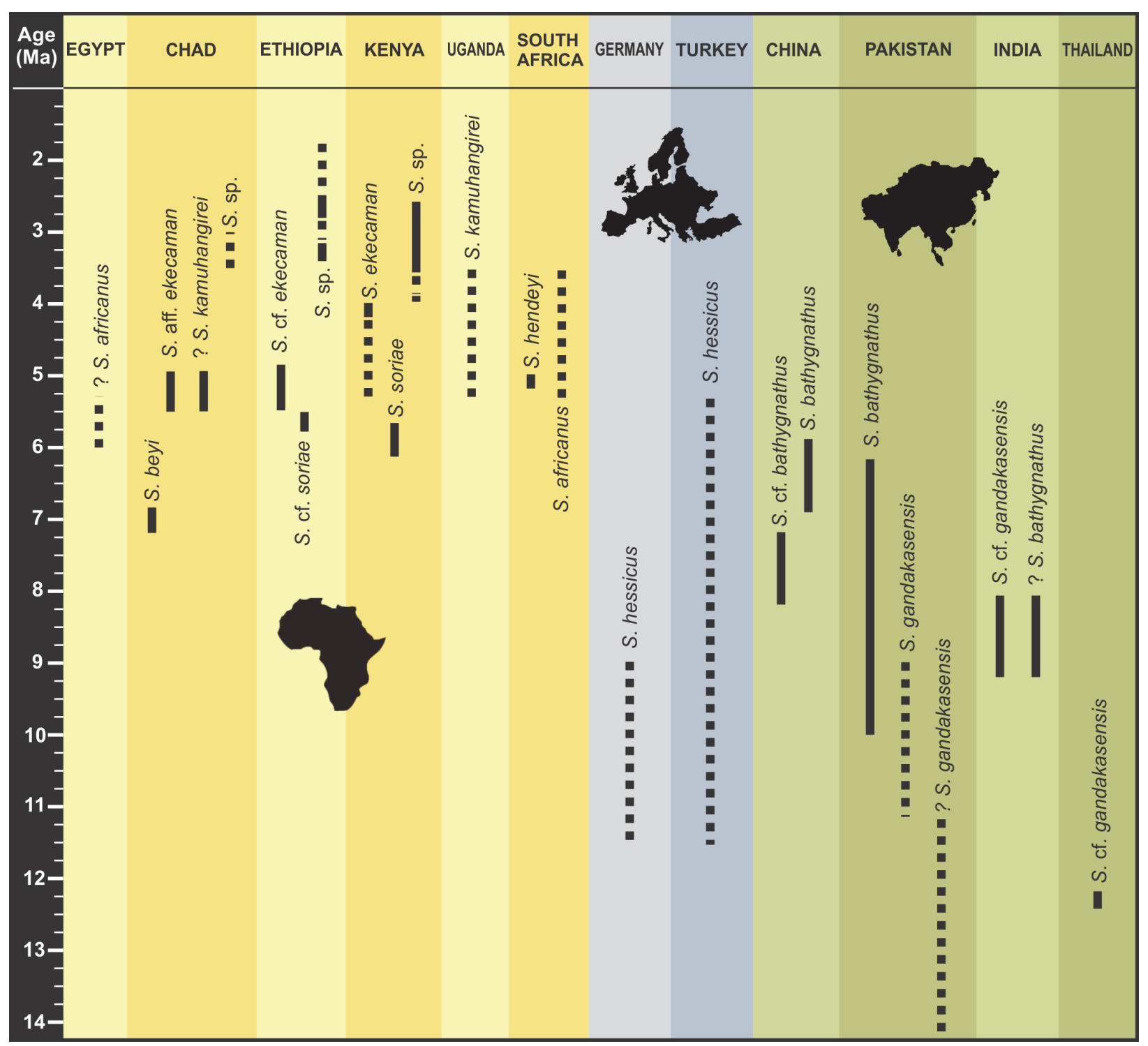

FIGURE 2. Stratigraphic and geographic distribution of Sivaonyx species in Africa, Europe and Asia. We used Barry et al. 2002, Qi et al. 2006, Pickford 2007, Coster et al. 2010 and Patnaik et al. 2013 for the datation of Asian localities and Werdelin and Sanders 2010 and references therein for African ones. Dotted lines indicate imprecise datations.

material described by Pilgrim (1932) and Colbert (1935) permits to compare the morphology of the lower carnassial with our material: CM-03-A differs from GSI D 156 and AM 19509 by smaller proportions, a narrower and longer paraconid, a higher protoconid compared to the paraconid instead of a similar height of these cusps and a narrower talonid basin. Moreover, CM-03-A differs from the $\mathrm{m} 1$ of Sivaonyx cf. bathygnathus from Yuanmou (YV 2517, figured by Zong, 1997) in being smaller and exhibiting a narrower talonid basin. The only M1 described as $S$. bathygnathus comes from Lufeng (IVPP V 6886.5, figured by Qi, 1983). A very similar M1 coming from Pakistan (loc.D013 dated to
6.3 m.y.) and stored in the Harvard Peabody Museum collections (GSP-Y16790) has been directly observed and thus allows more comparisons. CM-03-B differs from these specimens in being narrower, and in having a more developed paracone labial shelf, a less prominent metaconule, a less trenchant paraconule-protocone blade and a less extended distolingual shelf.

The more recent revision of bunodont otters from the Siwaliks provided by Pickford (2007) lead to the erection of a new species, S. gandakasensis, for the oldest Sivaonyx forms of Pakistan. CM03-A is very close to the $\mathrm{m} 1$ of $S$. gandakasensis by comparisons with morphological features of the 


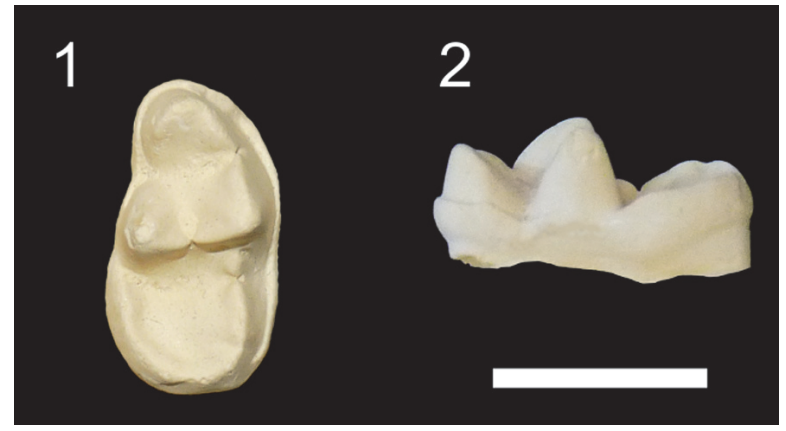

FIGURE 3. Sivaonyx cf. gandakasensis from the Late Miocene of Haritalyangar, India: cast of YPM 20206, right $\mathrm{m} 1$ in occlusal (1) and lingual (2) views. Scale = $1 \mathrm{~cm}$.

holotype GSP-Y 4225 and with the dimensions of the referred material. The cuspule at the distal base of the protoconid is less distinct than in CM03-A, but this feature is certainly variable within Sivaonyx species, as observed for the Potwar Plateau material of the Harvard Peabody Museum collections referred to $S$. bathygnathus. Moreover, the specimens of $S$. gandakasensis exhibit generally worn cusps, which prevent us from checking whether the protoconid is higher than the paraconid and metaconid. An isolated $\mathrm{m} 1$ from Haritalyangar observed in the YPM collections (YPM 20206, cast illustrated here for the first time, Figure 3 ) shows striking morphological similarities with the holotype of $S$. gandakasensis. This Indian lower carnassial displays a higher protoconid compared to the metaconid, as in the Chiang Muan material. The closer morphology of YPM 20206 with the holotype of $S$. gandakasensis rather than with the specimens referred to the type species (e.g., shorter paraconid, higher protoconid, narrower talonid basin) and the need of taxonomic revision of the specimens published by Prasad in 1968, which some do not belong to otters (Morales and Pickford, 2011), sow doubts on the presence of $S$. bathygnathus in Haritalyangar. Finally, Pickford (2007) attributed a mandible (BMNH G 4) from the Middle Miocene of Chhorwali Katas, northern Pakistan, to Vishnuonyx chinjiensis. However, the holotype of this species is an upper carnassial and the only dental material bearing $\mathrm{m} 1$ (GSI D 245, figured by Pilgrim, 1932) shows a lower carnassial with a narrower talonid basin and a less rounded outline of the distal talonid compared to that of BMNH G 4. This specimen is compared here because its morphology rather recalls that of Sivaonyx gandakasensis than that of Vishnuonyx chinjiensis. In comparison with the lower carnassial of our Thai material, the $\mathrm{m} 1$ of BMNH G 4 is slightly smaller and exhibits a less distinct cuspule at the base of the protoconid, a more distinct hypoconid, and a lingual cingulid extending until the metaconid base. Both Indian and Thai specimens compared in this paper can be referred to $S$. cf. gandakasensis until additional material from Haritalyangar and Chiang Muan are found.

The European species S. hessicus is represented by a mandible (BMNH M 27486) from the Late Miocene of Eppelsheim, in Germany (Lydekker, 1890) and listed from the Miocene of KutchukTchekmedjè locality, in Turkey (Nicolas, 1978). The holotype of $S$. hessicus shows an $\mathrm{m} 1$ very close morphologically to CM-03-A (e.g., protoconid higher than the paraconid, narrow talonid basin, distinct cuspule at the distal base of the protoconid). Only the trigonid lingual valley is narrower and the lingual cingulid extends under the metaconid, unlike in our Thai material. Moreover, the $\mathrm{m} 1$ has larger dimensions than CM-03-A. Originally attributed to Lutra (Lydekker, 1890), Pilgrim (1931) moved the holotype of the European species to Sivaonyx, considering the strong morphological similarities with $S$. bathygnathus from the Indian Subcontinent. Pickford (2007) agreed with Pilgrim's attribution and even suggested a synonymy with the Asian species. However, S. hessicus is clearly closer morphologically to $S$. gandakasensis than to $S$. bathygnathus (e.g., narrower paraconid, protoconid higher than the metaconid and paraconid, narrower talonid basin).

Sivaonyx beyi from the Late Miocene of Toros-Menalla, Chad, is the oldest representative of the genus in Africa (Peigné et al., 2008). The m1s (TM 247-01-005 and TM 355-02-002) differ from CM-03-A by a deeper valley between the paraconid and protoconid with a more oblique distolingual crest of the paraconid, a protoconid lower than the metaconid (TM 355-02-002) or approximately equal to it (TM 247-01-005), a less distinct cuspule at the distal base of the protoconid, a nearly horizontal lingual rim of the talonid, and a deeper talonid basin. The M1 (TM 90-00-066) differs from CM-03-B in being longer and wider, in having a poorly developed paracone labial shelf and a shorter parastyle, an oblique and a more trenchant paraconule-protocone blade, a crest descending mesiolingually from the metaconule. The highest part of the distolingual cingulum is also directly lingual to the metacone rather than mesial to it.

Sivaonyx soriae is recorded in the Late Miocene Lukeino Formation, Kenya (Morales and Pickford, 2005). The occurrence of this species in 
the Lukeino beds has been originally based on lower dental specimens. Upper isolated teeth from the same locality initially attributed to $S$. senutae are now considered as synonym based on their suitable dental morphology and on the range of intraspecific size variation within Sivaonyx species (i.e., S. hendeyi and S. ekecaman; see Peigné et al., 2008 for details). S. cf. soriae is also reported by a fragment of P4 from the Late Miocene of the Asa Koma Member, Adu Asa Formation, in Ethiopia (Haile-Selassie, 2008). Moreover, S. aff. ekecaman occurs in the locality of Kossom Bougoudi, Chad, at the Mio-Pliocene boundary (Bonis et al. 2008). The $\mathrm{m} 1 \mathrm{~s}$ of $\mathrm{S}$. soriae (KNM LU 337 and BAR 1984'05) differ from CM-03-A by a wider metaconid, resulting in a less opened trigonid and a more oblique protocristid, a metaconid higher than the protoconid, a wider talonid relative to the trigonid, and a deeper talonid basin. The M1 (BAR 1082'01) differs from CM-03-B in being wider and mostly longer, in having an oblique paraconule-protocone blade with a protocone closer to the lingual rim of the tooth, and a metaconule closer to the metacone.

Sivaonyx ekecaman has been recovered from the Early Pliocene of the Kanapoi Formation (Werdelin, 2003) and of the Magabet Formation, in Kenya (Morales and Pickford, 2005). S. cf. ekecaman is also reported from the latest Miocene and earliest Pliocene of the Kuseralee and Haradaso Members, Sagantole Formation, in the Middle Awash of the Afar rift, in Ethiopia (Haile-Selassie, 2008). Moreover, S. aff. ekecaman occurs in the locality of Kossom Bougoudi, Chad, at the MioPliocene boundary (Bonis et al. 2008). The m1s differ from CM-03-A by very low cusps (hypoconidprotoconid-paraconid of similar height on KNMKP10034b), an oblique distolingual crest of the paraconid which joins the mesial crest descending from the metaconid to close the trigonid lingual valley, a nearly complete fusion of the basal cuspule of the talonid with the distal face of the protoconid, and a very wide and more basined talonid bordered by cuspules. The M1 (KNM-KP10034c) is distinct from that of the Chiang Muan otter by a narrower paracone labial shelf, a bulbous parastyle, an oblique paraconule-protocone blade, a protocone close to the lingual rim of the tooth, a more extended distolingual cingulum resulting in a distal position of its highest part relative to the metacone, and in unparallel mesial and distal borders of M1.

Sivaonyx africanus is recorded from the Early Pliocene of Klein Zee, South Africa, and possibly the Late Miocene of Wadi Natrun, Egypt (Stromer, 1931; Morales and Pickford, 2005; Pickford, 2007). The mandible and the associated M1 (BSPG 1930 $X I$ 1) from South Africa are compared here. The $\mathrm{m} 1$ shows a wider talonid basin, a metaconid higher than the protoconid, protoconid and paraconid of similar height, a less distinct cuspule at the distal base of the protoconid, and a less opened trigonid lingual valley compared to CM-03-A. The M1 is again wider and mostly longer, and shows an oblique paraconule-protocone blade, a protocone closer to the lingual rim of the tooth, a metaconule closer to the metacone, and an extended distolingual cingulum unlike CM-03-B.

Sivaonyx hendeyi from the earliest Pliocene of Langebaanweg, in South Africa (Morales et al., 2005), shows on its mandible (SAM PQ-L 50000) a more bunodont $\mathrm{m} 1$ than $\mathrm{CM}-03-\mathrm{A}$ with very low cusps, a thicker mesial cingulid, a metaconid higher than the protoconid, a narrower trigonid lingual valley, a poorly distinct cuspule at the distal base of the protoconid, and an entoconid crest higher than the hypoconid one.

Sivaonyx kamuhangirei is reported in the Early Pliocene Kazinga Beds and Warwire Formation of Nkondo area, Uganda (Morales and Pickford, 2005). It is possibly present in the latest Miocene-earliest Pliocene Chadian locality of Kossom Bougoudi (Bonis et al. 2008). The holotype (unnumbered specimen from Kazinga, figured in Morales and Pickford, 2005) differs from CM-03-A by a narrower trigonid lingual valley, a more oblique hypoconid crest, and a stronger entoconid.

Overall, all African species show a more derived dental morphology compared to Sivaonyx cf. gandakasensis and Eurasian forms by displaying more bunodont teeth with notably larger proportions, a lower $\mathrm{m} 1$ protoconid, and a shorter and wider paraconid. Within Eurasian species, $S$. bathygnathus displays a more derived dental morphology compared to $S$. gandakasensis and $S$. hessicus (e.g., wider $\mathrm{m} 1$, reduction of the parastyle and distolingual extension on M1) and thus appears closer to the African species of Sivaonyx.

\section{DISCUSSION}

Miocene bunodont otters include the genera Vishnuonyx, Djourabus, Paludolutra, Sivaonyx, and possibly Enhydriodon (Willemsen, 1992; Pickford, 2007; Peigné et al., 2008). Much generic confusion has been experienced for the last three taxa. In the European genus Paludolutra, P. Iluecai was considered as a species of Enhydriodon (Villalta and Crusafont-Pairó, 1945) then Sivaonyx (Alcalá, 
1994), and P. maremmana and P. campanii were assigned to Enhydriodon (Forsyth Major, 1873), a suggestion followed later by many authors. Now these species belong with a general acceptance to Paludolutra, mainly based on the morphology of their upper dentition. The attribution of fossil specimens to either Sivaonyx or Enhydriodon is problematic because the fragmentary material shows poor morphological differences, especially the lower carnassial, and because the stratigraphic occurrence of Enhydriodon type species in the Siwalik Hills is uncertain (Pilgrim, 1932). Unlike Paludolutra, the confusion between Sivaonyx and Enhydriodon is still ongoing, mostly for African forms: the species "S." africanus, "S." ekecaman, and "S." hendeyi are assigned either to Sivaonyx (e.g., Morales and Pickford, 2005; Peigné et al., 2008) or to Enhydriodon (e.g., Geraads et al., 2011). The closer morphological resemblance of the Chiang Muan otter with the type species $S$. bathygnathus rather than with African otters, and its older age, allow us to consider this taxon as a Sivaonyx species with confidence. Even if some African forms could be related to Enhydriodon, it is likely that they belong to the same bunodont lineage whose primitive features are exhibited by our Thai specimens. These features are a long and narrow paraconid, a high protoconid, a narrow talonid basin and a well-distinct cuspule at the distal base of the protoconid of $\mathrm{m} 1$, associated with a wide paracone labial shelf and a more rectangular shape of M1 (i.e., much wider than long and with parallel mesial and distal borders).

The lutrine material from Chiang Muan Basin brings new support for the hypothesis of a unique biogeographical province during the Middle Miocene comprising Southeast Asia and the Siwalik Hills (Ducrocq et al., 1994; Chavasseau et al., 2006). This has been previously revealed by the common contemporaneous and exclusive presence of the rhinocerotid Chilotherium intermedium and the suoids Pecarichoerus sminthos and Conohyus sindiensis in Chiang Muan and in the Potwar Plateau, the latter species also occurring in several localities of the Mae Moh Group of northern Thailand (Pickford et al., 2004; Chavasseau et al., 2006; Suganuma et al., 2006). The geographical distribution of $S$. gandakasensis could also be larger than those of all known African Sivaonyx species. Currently living areas of otters are variable among species. For instance, Aonyx capensis is present in Southern Africa, northwards to Ethiopia to the east and in Western Africa (Larivière, 2001a) whereas Aonyx congicus occurs in central
Africa (Larivière, 2001b). The presence of a unique otter species in the Middle-Late Miocene of Southern Asia may traduce similar environmental conditions between Pakistan, India, and northern Thailand. The sediments from the Ban Sa Mudstone Formation of the Chiang Muan Basin indicate a fluviolacustrine and swamp environment (Chaimanee et al., 2007). Moreover, pollen sampled from the Upper Lignite Member of this locality reveal warm and moist climate conditions with the presence of a mosaic of tropical freshwater swamps dominated by the lowland forest taxon Syzygium (Chaimanee et al., 2003; Sepulchre et al., 2010). Similarly, Haritalyangar deposits suggest a river flood plain setting including an open forest vegetation with patches of bamboo (Pillans et al., 2005), and the Potwar Plateau of Pakistan shows during the Early and Middle Miocene extensive river flood plain systems that might have contained a wide variety of habitats, from woodlands to bush and grasslands near the large streams (Barry and Flynn, 1990).

Data from postcranial remains of African bunodont otters, such as Sivaonyx species, indicate different locomotion patterns, ranging from semi-aquatic to fully aquatic (Lewis, 2008). The study of the postcranial anatomy of $S$. beyi, the oldest African species, suggests that this otter was a poorly specialized swimmer and probably a terrestrial predator (Peigné et al., 2008). Even if no postcranial remains of Asian Sivaonyx species are known, one can assume the capacity of long distance travelling on land, as in modern otters, following freshwater system, as Sivaonyx fossil remains are always associated with lacustrine and/ or fluvial paleoenvironments. Moreover, the derived dental morphological features of African Sivaonyx species compared to Eurasian ones and the closer similarity of S. bathygnathus with African Sivaonyx species could suggest a dispersal event from Asia to Africa probably during the Late Miocene (between ca. 10 and 7 m.y.). Other bunodont otters could have immigrated to Africa from Asia during the Mio-Pliocene: the genus Vishnuonyx (considered as the ancestor of bunodont otters) during the Middle Miocene, and possibly the genus Enhydriodon during the Late Miocene/Pliocene. The Middle Miocene carnivoran faunas from Southeast Asia (e.g., Peigné et al., 2006; Grohé et al., 2010) along with further fieldwork efforts in the Miocene of Southern Asia promise to improve our comprehension of the evolutionary history of Carnivora as well as the relevance of Neogene biogeographic scenarii between the Old World continents. 


\section{ACKNOWLEDGEMENTS}

This work was supported by the University of Poitiers, the ANR-09-BLAN-0238 and a young researcher award from the Fondation des Treilles. We would like to thank J. Barry, L.J. Flynn, D. Pilbeam (Harvard Peabody Museum) and D. Brinkman (Yale Peabody Museum) for kindly allowing us access to the fossil collections of the Siwaliks, notably unpublished material. We are also grateful to $\mathrm{S}$. Peigné $(\mathrm{MNHN})$ and L. Werdelin (SMNH Stockholm) for providing photos of some specimens compared in this study and for helpful discussions on bunodont otters. We would like to thank all the team working on the Chiang Muan field as well as M. Rugbumrung (DMR) and X. Valentin (iPHEP) for their technical support, and C. Noël and G. Florent (iPHEP) for their administrative guidance. The first author also thanks the team of the paleontological department of the Institut des Sciences de l'Évolution, University of Montpellier.

\section{REFERENCES}

Alcalá, L. 1994. Macromammiferos Neogenos de la Fosa de Alfambra-Teruel. Museo Nacional de Ciencias Naturales, Madrid.

Barry, J.C. and Flynn, L.J. 1990. Key biostratigraphic events in the Siwaliks sequence, p. 557-571. In Lindsay, E.H., Falbusch, V., and Mein, P. (eds.), European Neogene Mammal Chronology. Plenum Press, New York.

Barry, J.C., Lindsay, E.H., and Jacobs, L.L. 1982. A biostratigraphic zonation of the Middle and Upper Siwaliks of the Potwar Plateau of northern Thailand. Palaeogeography, Palaeoclimatology, Palaeoecology, 37:95-130.

Barry, J.C., Morgan, M.E., Flynn, L.J., Pilbeam, D., Behrensmeyer, A.K., Raza, S.M., Khan, I.A., Badgley, C., Hicks, J., and Kelley, J. 2002. Faunal and Environmental Change in the Late Miocene Siwaliks of Northern Pakistan. Paleobiology, 28:1-71.

Benammi, M., Chaimanee, Y., Urrutia-Fucugauchi, J., and Jaeger, J.-J. 2004. Magnetostratigraphic Study of the Continental Sedimentary Sequence of the Chiang Muan Basin, Northern Thailand: Implications for the Age of the First Miocene Hominoids from Thailand. International Geology Review, 46:646-654.

Bonaparte, C.L. 1838. Synopsis Vertebratorum Systematis. Nuovi Annali delle Scienze Naturali Bologna, 2:105-133.

Bonis, L. de, Peigné, S., Mackaye, H.T., Likius, A., Vignaud P., Brunet, M. 2008. The fossil vertebrate locality Kossom Bougoudi, Djurab desert, Chad : A window in the distribution of the carnivoran faunas at the Mio-Pliocene boundary in Africa. Comptes Rendus Palevol, 7:571-581.
Bowdich, T.E. 1821. An Analysis of Natural Classifications of Mammalia for the Use of Students and Travellers. J. Smith, Paris.

Chaimanee, Y., Jolly, D., Benammi, M., Tafforeau, P., Duzer, D., Moussa, I., and Jaeger, J.-J. 2003. A Middle Miocene hominoid from Thailand and orangutan origins. Nature, 422:61-65.

Chaimanee, Y., Yamee, C., Tian, P., and Jaeger, J.-J. 2007. Diversity of cenozoic mammals in Thailand: Paleoenvironment and age updated, International Conference on Geology of Thailand: Towards Sustainable Development and Sufficiency Economy, pp. 73-79.

Chaimanee, Y., Suteethorn, V., Jintasakul, P., Vidthayanon, C., Marandat, B., and Jaeger, J.-J. 2004. A new orang-utan relative from the Late Miocene of Thailand. Nature, 427:439-441.

Chavasseau, O., Chaimanee, Y., Yamee, C., Tian, P., Rugbumrung, M., Marandat, B., and Jaeger, J.-J. 2009. New Proboscideans (Mammalia) from the middle Miocene of Thailand. Zoological Journal of the Linnean Society, 155:703-721.

Chavasseau, O., Chaimanee, Y., Tun, S.T., Soe, A.N., Barry, J.C., Marandat, B., Sudre, J., Marivaux, L., Ducrocq, S., and Jaeger, J.-J. 2006. Chaungtha, a new Middle Miocene mammal locality from the Irrawaddy Formation, Myanmar. Journal of Asian Earth Sciences, 28:354-362.

Colbert, E.H. 1935. Siwalik Mammals in the American Museum of Natural History. Transactions of the American Philosophical Society, 26:1-401.

Coster, P., Benammi, M., Chaimanee, Y., Yamee, C., Chavasseau, O., Emonet, E.-G., and Jaeger, J.-J. 2010. A complete magnetic polarity stratigraphy of the Miocene continental deposits of Mae Moh basin, northern Thailand and a reassessment of the age of hominoid bearing localities in northern Thailand. Geological Society of America Bulletin, 122:11801191.

de Muizon, C. 1982. Les relations phylogénétiques des Lutrinae (Mustelidae, Mammalia). Geobios, 6:259277.

Ducrocq, S., Chaimanee, Y., Suteehorn, V., and Jaeger, J.-J. 1994. Ages and paleoenvironment of Miocene mammalian faunas from Thailand. Palaeogeography, Palaeoclimatology, Palaeoecology, 108:149-163.

Fischer, G. 1817. Adversaria Zoologica. Mémoires de la Société Impériale des naturalistes de Moscou, 5:357472.

Flower, W.H. 1869. On the value of the characters of the base of the cranium in the classification of the Order Carnivora and the systematic position of Bassaris and other disputed forms. Proceedings of the Zoological Society of London, 37:4-37.

Forsyth Major, C. 1873. Les faunes des vertébrés de Monte Bamboli (Maremmes de la Toscane). Atti della Societa Italiana di Scienze Naturali, 15:290-303. 
Geraads, D., Alemseged, Z., Bobe, R., and Reed, D. 2011. Enhydriodon dikikae, sp. nov. (Carnivora: Mammalia), a Gigantic Otter from the Pliocene of Dikika, Lower Awash, Ethiopia. Journal of Vertebrate Paleontology, 31:447-453.

Grohé, C., Chaimanee, Y., Bonis, L. de, Yamee, C., Blondel, C., and Jaeger, J.-J. 2010. New data on Mustelidae (Carnivora) from Southeast Asia: Siamogale thailandica, a peculiar otter-like mustelid from the late Middle Miocene Mae Moh Basin, northern Thailand. Naturwissenschaften, 97:1003-1015.

Haile-Selassie, Y. 2008. New observations on the Late Miocene-Early Pliocene Lutrinae (Mustelidae: Carnivora, Mammalia) from the Middle Awash, Afar Rift, Ethiopia. Comptes Rendus Palevol 7:557-569.

Koepfli, K.-P. and Wayne, R.K. 1998. Phylogenetic relationships of otters (Carnivora: Mustelidae) based on mitochondrial cytochrome $b$ sequences. Journal of Zoology (London), 246:401-416.

Koepfli, K.-P., Kanchanasaka, B., Sasaki, H., Jacques, H., Louie, K.D.Y., Hoai, T., Xuan Dang, N., Geffen, E., Gutleb, A., Han, S.-y., Heggberget, T.M., La Fontaine, L., Lee, H., Melisch, R., Ruiz-Olmo, J., SantosReis, M., Sidorovich, V.E., Stubbe, M., and Wayne, R.K. 2008. Establishing the foundation for an applied molecular taxonomy of otters in Southeast Asia. Naturwissenschaften, 9:1589-1604.

Kretzoi, M. 1943. Kochitis centenii n. gen. n. sp., ein altertümlicher Creodonte aus dem Oberoligozän Siebenbürgens. Földtany Közlöny, 52:10-195.

Larivière, S. 2001a. Aonyx capensis. Mammalian species, 671:1-6.

Larivière, S. 2001b. Aonyx congicus. Mammalian species, 650:1-3.

Lewis, M.E. 2008. The femur of extinct bunodont otters in Africa (Carnivora, Mustelidae, Lutrinae). Comptes Rendus Palevol 7:607-627.

Lydekker, R. 1884. Indian Tertiary and post-Tertiary Vertebrata: Siwalik and Narbada Carnivora. Memoirs of the Geological Survey of India, Palaeontologia Indica, 10:178-355.

Lydekker, R. 1890. On a new species of otter from the lower Pliocene of Eppelsheim. Proceedings of the Zoological Society of London, 1890:3-5.

Morales, J. and Pickford, M. 2005. Giant bunodont Lutrinae from the Mio-Pliocene of Kenya and Uganda. Estudios Geologicos, 61:233-246.

Morales, J. and Pickford, M. 2011. A new paradoxurine carnivore from the Late Miocene Siwaliks of India and a review of the bunodont viverrids of Africa. Geobios, 44:271-277.

Morales, J., Pickford, M., and Soria, D. 2005. Carnivores from the Late Miocene and Basal Pliocene of the Tugen Hills, Kenya. Revista de la Sociedad Geológica de España, 18:39-61.

Nicolas, P.J. 1978. Un nouveau gisement de Vertébrés dans le Chersonien: Kutchuk-Tchekmedjè Ouest (Thrace turque). Comptes Rendus de l'Académie des Sciences, 287:455-458.
Patnaik, R. 2013. Indian Neogene Siwalik Mammalian Biostratigraphy: An overview, p. 423-444. In Wang, X., Flynn, L.J., and Fortelius, M. (eds.), Fossil Mammals of Asia: Neogene Biostratigraphy and Chronology. Columbia University Press, New York.

Peigné, S., Chaimanee, Y., Yamee, C., Tian, P., and Jaeger, J.-J. 2006. A new amphicyonid (Mammalia, Carnivora, Amphicyonidae) from the late Miocene of northern Thailand and a review of the amphicyonine record in Asia. Journal of Asian Earth Sciences, 26:519-532.

Peigné, S., de Bonis, L., Likius, A., Mackaye, H.T., Vignaud, P., and Brunet, M. 2008. Late Miocene Carnivora from Chad: Lutrinae (Mustelidae). Zoological Journal of the Linnean Society, 152:793-846.

Pickford, M. 2007. Revision of the Mio-Pliocene bunodont otter-like mammals of the Indian Subcontinent. Estudios geologicos, 63:83-127.

Pickford, M. and Liu, L. 2001. Revision of the Miocene Suidae of Xiaolongtan (Kaiyuan), China. Bulletino della Societa Paleontologica Italiana, 40:275-283.

Pickford, M., Nakaya, H., Kunimatsu, Y., Saegusa, H., Fukuchi, A., and Ratanasthien, B. 2004. Age and taxonomic status of the Chiang Muan (Thailand) hominoids. Comptes Rendus Palevol, 3:65-75.

Pilgrim, G.E. 1931. Catalogue of the Pontian Carnivora of Europe in the Department of Geology, British Museum (Natural History), London.

Pilgrim, G.E. 1932. The fossil Carnivora of India. Memoirs of the Geological Survey of India, Palaeontologia indica, 18:1-232.

Pillans, B., Williams, M., Cameron, C., Patnaik, R., Hogarth, J., Sahni, A., Sharma, J.C., Williams, F., and Bernor, R.L. 2005. Revised correlation of the Haritalyangar magnetostratigraphy, Indian Siwaliks: implications for the age of the Miocene hominids Indopithecus and Sivapithecus, with a note on a new hominid tooth. Journal of Human Evolution, 48:507515.

Prasad, K.N. 1968. The vertebrate fauna from the Siwalik beds of Haritalyangar, Himachal Pradesh, India. Memoirs of the Geological Survey of India, Paleontologia Indica, 39:1-55.

Qi, G. 1979. Pliocene mammalian fauna of Lufeng, China Vertebrata PalAsiatica, 17:14-22.

Qi, G. 1983. Description of Carnivora fossils from Lufeng. Acta Anthropologica Sinica, 2:11-20.

Qi, G., Dong, W., Zheng, L., Zhao, L., Gao, F., Yue, L., and Zhang, Y. 2006. Taxonomy, age and environment status of the Yuanmou hominoids. Chinese Science Bulletin, 51:704-712.

Sepulchre, P., Jolly, D., Ducrocq, S., Chaimanee, Y., Jaeger, J.-J., and Raillard, A. 2010. Mid-Tertiary paleoenvironments in Thailand: pollen evidence. Climate of the Past, 6:461-473. 
Stromer, E. 1931. Reste Süsswasser und Land bewohnender Wirbeltiere aus den Diamantfeldern Klein-Namaqualandes (Südwest Afrika). Sitzungsberichte der Mathematisch-Naturwissenschaftlichen Abteilung der Bayerischen Akademie der Wissenschaften zu München, 1:17-47.

Suganuma, Y., Hamada, T., Tanaka, S., Okada, M., Nakaya, H., Kunimatsu, Y., Saegusa, H., Nagaoka, S., and Ratanasthien, B. 2006. Magnetostratigraphy of the Miocene Chiang Muan Formation, northern Thailand: Implication for revised chronology of the earliest Miocene hominoid in Southeast Asia. Palaeogeography, Palaeoclimatology, Palaeoecology, 239:75-86.

Suraprasit, K., Chaimanee, Y., Martin, T., and Jaeger, J.J. 2011. First Castorid (Mammalia, Rodentia) from the Middle Miocene of Southeast Asia. Naturwissenschaften, 98:315-328.

van Zyll de Jong, C.G. 1987. A phylogenetic study of the Lutrinae (Carnivora; Mustelidae) using the morphological data. Canadian Journal of Zoology, 65:25362544.

van Zyll de Jong, C.G. 1991. A brief review of the systematics and a classification of the Lutrinae, p. 79-83. In Reuther, C. and Röchert, R. (eds.), Proceedings of the V International Otter Colloqium, Habitat 6, Hankensbüttel 1989.
Villalta, J.F., and Crusafont-Pairó, M. 1945. Enhydriodon lluecai $\mathrm{n}$. sp. el primer lútrido del Pontiense español. Boletin de la Real Sociedad Española de Historia Natural, $43: 383-396$.

Werdelin, L. 2003. Carnivora from the Kanapoi Hominid site, Turkana Basin, Northern Kenya, p. 115-132. In Harris, J.M. and Leakey, M.G. (eds.), Geology and Vertebrate Paleontology of the Early Pliocene Site of Kanapoi. Contributions in Science, Los Angeles.

Werdelin, L. and Peigné, S. 2010. Carnivora, p. 609-663. In Werdelin, L., and Sanders, W.J. (eds.), Cenozoic Mammals of Africa. University of California Press, Berkeley.

Werdelin, L. and Sanders, W.J. 2010. Cenozoic Mammals of Africa. University of California Press, Berkeley.

Willemsen, G.F. 1992. A revision of the Pliocene and Quaternary Lutrinae from Europe. Scripta Geologica, 101:1-115.

Zong, G. 1997. Carnivora, p. 69-89. In He, Z.-q. (ed.), Yunamou Hominoid Fauna. Yunnan Science \& Technology Press, Kunming. 